\title{
APPLICATION OF OPEN AND / OR FREE GEO-TECHNOLOGIES TO COMBAT THE WATER LOSS IN A SUPPLY SYSTEM
}

\author{
Vinícius de Oliveira RIBEIRO \\ Antonio Conceição PARANHOS FILHO² \\ Flávia Maria FOGAÇA ${ }^{1}$
}

\begin{abstract}
The water supply in sufficient quantity and quality is one of the priorities for populations. Due to the shortage of resources and the priority in the costs with the water supply and the expenses with commercial available GIS, the application of open and/or free geo-technologies is relevant. This study aims to combat losses in a water supply system, made a composition in a GIS databank, focusing on the spatial display of repair and maintenance services in the water network. The patterns in the demands of the work that led to the establishment of preventive maintenance routines were identified, resulting in the gradual reduction of losses in the municipality of Coronel Sapucaia / Mato Grosso do Sul State.
\end{abstract}

Key words: Loss index. Geo-technologies. GIS. gvSIG.

\section{Resumo}

\section{Aplicação de geotecnologias livres e/ou gratuitas no combate à perda de água em sistema de abastecimento de água}

O abastecimento de água em quantidade e qualidade suficientes são uma das prioridades das populações. A escassez de recursos e a prioridade nos custos com o abastecimento faz com que ferramentas que auxiliem em melhorar o desempenho do sistema de abastecimento recebam pouco investimento e sejam pouco utilizadas, como as ferramentas de geotecnologias, que possuem custos elevados quanto a aquisição dos principais Sistemas de Informação Geográfica - SIG comerciais disponíveis no mercado. O presente estudo, com vistas ao combate a perdas no sistema de abastecimento de água, efetuou a composição do banco SIG, com enfoque na espacialização dos serviços de reparo e manutenção na rede de água tratada. Foram identificados os padrões nas demandas dos trabalhos que levaram ao estabelecimento de rotinas de manutenção preventiva, resultando na redução no índice de perda gradual no município de Coronel Sapucaia/MS.

Palavras-chave: Índice de perdas. Geotecnologias. SIG. gvSIG.

\footnotetext{
1 Universidade Estadual de Mato Grosso do Sul - UEMS. Rodovia Dourados-Itahum, km 12, Cidade Universitária - Mailbox 351. 79804-970 - Dourados - MS, Brasil. E-mails: viniciusoribeiro@yahoo.com.br; flaviamariafogaca@gmail.com

2 Universidade Federal de Mato Grosso do Sul -UFMS. Cidade Universitária - Mailbox 549.79070900 - Campo Grande - MS, Brasi. E-mail: toniparanhos@gmail.com
} 


\section{INTRODUCTION}

One of the municipality main priorities is the provision of an adequate quantity and quality of water in the supply systems, guaranteeing the fulfillment of the population needs related to health and industrial development (TSUTIYA, 2006).

Brazil intends, until 2030, to universalize the access to basic sanitation services as a social right, including the components: drinking water supply, sewage treatment, urban cleaning and solid waste management, and drainage of rainwater, as stated by the Plano Nacional de Saneamento Básico - PLANSAB (BRASIL, 2012).

In order to achieve these goals, the optimization of resources is imperative, as well as to combat water losses in existing supply systems, which often do not receive the necessary preventive maintenance, with frequent remediation problems (MCKIBBEN, 1994). Measures to control losses, mapping of occurrences and global analysis of the system are fundamental to reduce waste of treated water and combat frauds (GOMES, 2002).

Considering the high number of variables related to the analysis of existing water supply systems, the initial problem is to obtain information of its quality and quantity with the least possible burden. From this perspective, remote sensing, a technique to obtain information about an object, an area or phenomenon on Earth, without direct physical contact with it, is a precise tool, generating information to permanently record any region of technical or scientific interest, being a basic tool to guide planning actions (RAMOS et al., 2004).

In order to use the tools that allow the analysis of these data effectively, correlating all the parameters simultaneously, the Geographic Information System GIS and geoprocessing techniques, constitute one of the most appropriate tools for the treatment of a big amount of spatially related data, aiming to solve complex planning problems (SIKORSKI, 1996).

The spatial information allows the improvement of the analysis of problems, permitting the simultaneous evaluation of multiple data. The scenario in question may assist the identification of patterns from the occurrence of treated water leakage in a water supply system, which is difficult to record in spot checks, outside of a wider context provided by GIS.

In order to minimize costs, it was decided to work with the gvSIG version 2.2 (VALENCIANA, 2012). It is free open source GIS software. The source code can be accessed and modified to satisfy user conditions, developed by the Conselleria d'Infraestructures $i$ Transports - CIT of the Valencia Community, with the support of the European Union. It is distributed under the General Public License (GPL, version $3)$, with a free download on the website.

\section{RESEARCH OBJECTIVE}

Evaluate the use of a free GIS in a small city, aiming to control water losses in the supply system and the adequacy of the geo-technology to users, the possibilities of analysis offered, the maintenance and the GIS access to the local operators. 


\section{MATERIAL AND METHODS}

The selected area for the study was the municipality of Coronel Sapucaia/Mato Grosso do Sul State (Figure 1), selected because it is part of the Technical Cooperation Agreement signed between the Sanitation Company of Mato Grosso do Sul - SANESUL and the Federal University of Mato Grosso do Sul - UFMS. This city, with 14,064 inhabitants (IBGE, 2011), is located in the South of the Central-West region of Brazil, in SW of Mato Grosso do Sul State, bordering the city of Capitan Bado in Paraguay.
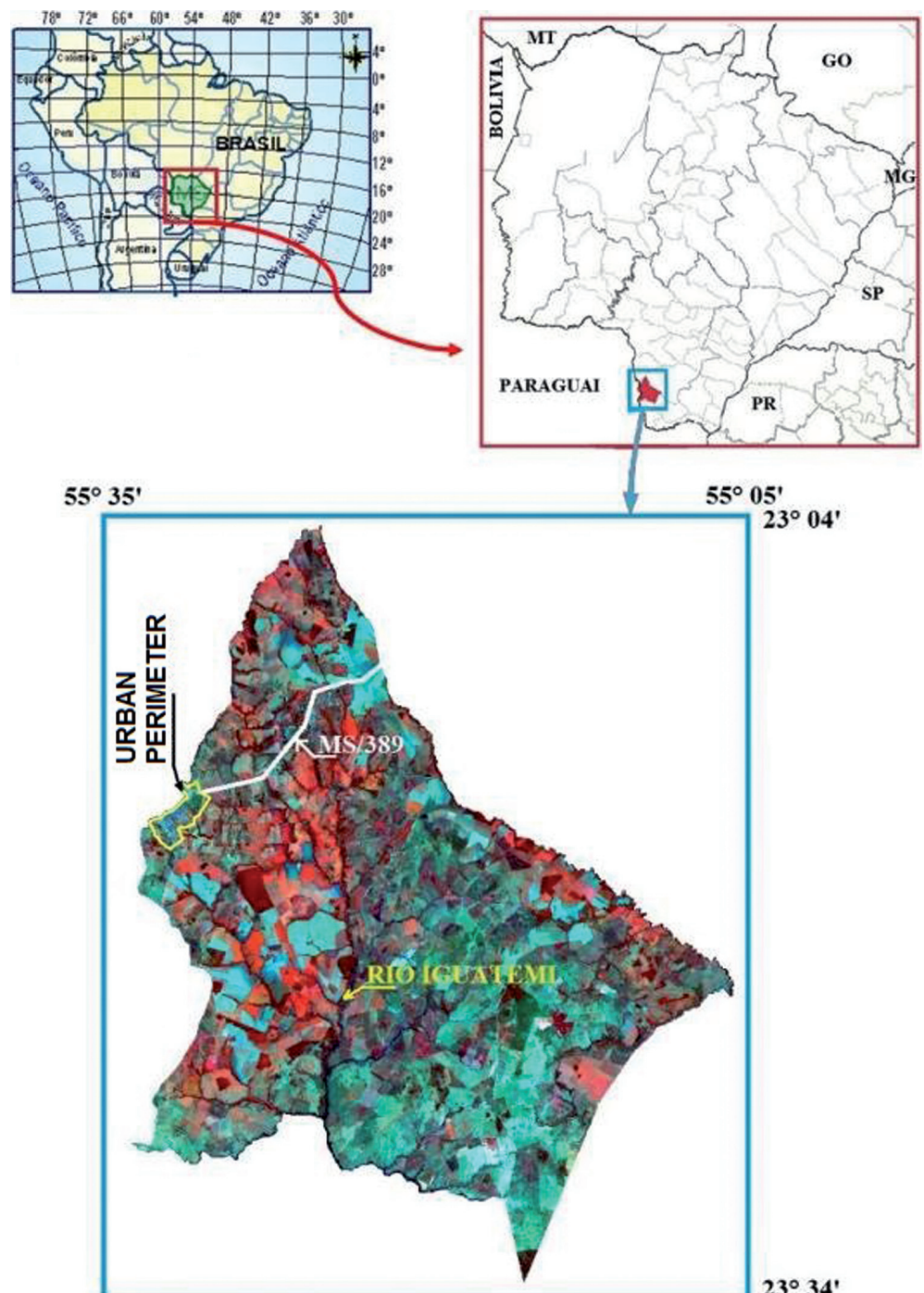
For the data acquisition, the geo-referencing of the vector base from SANESUL was carried out, which showed large distortions. Therefore, a planialtimetric survey and location of D-GPS reference points was made in this municipality.

The survey began with the implementation of a geodetic coordinate network, transported from Mark 92798 of the Instituto Brasileiro de Geografia e Estatística IBGE located in Amambaí/MS by a RTK Trimble R6 GPS equipment (millimeter accuracy equipment operating in real time). The implementation and geodetic survey of the landmarks aimed to support the topographical polygons checking and improving their respective precisions. The measurement of the landmarks was performed by satellite tracking of the RTK GPS system with a 5-minute tracking timeout. All landmarks and pickets had their altitudes determined by geometric levelling according to item 3.20 from NBR 13.133/94 (ABNT, 1994).

The support landmark stations were measured by tracking from satellites using GPS in the static mode applying geodetic precision receivers, namely, dual frequency receivers ( $C / A$ code and $\mathrm{L} 1$ and $\mathrm{L} 2$ carriers).

As the geodetic GPS receivers use a real-time system, the information collected in the field had its ambiguity corrected by RTK radio wave communication, not requiring a post-processing and extracting the coordinates in real time. The geodetic support frames were deployed in specific and relevant places, located in places with good visibility and protection, with the following configurations: top $0.15 \mathrm{~m} \times 0.40 \mathrm{~m}$; concrete base of $0.15 \mathrm{~m} \times 0.15 \mathrm{~m} ; 0.10 \mathrm{~m}$ above the ground.

As the survey started from a known georeferenced coordinate with the IBGE MS 11 landmark, post-processing through RBMC (Rede Brasileira de Monitoramento Contínuo) was not necessary.

For the survey, the reference altitude was the geometric altitude of the ellipsoid, collected from the MS11 geometric landmark described above. The field data were checked with the tolerance by carnet verification, and in the carnet reports.

From the field survey and expedited observations in the satellite image, the guidelines for the distribution of a support landmark network of reference in the RN'slevel (Figure 2) and its coordinates (Table 1) were elaborated, which were implemented in the urban area. The geometric method was adopted as leveling criterion, always accompanied by counter-leveling, leaving some level references at specific points of relevance for this study.

For the RN's, the criterion adopted was to materialize them in trunk concrete frames of $10 \times 10 \times 40 \mathrm{~cm}$, and in wooden pickets that later will be replaced by concrete marks.

In this survey, cadastral data were collected from the field polygons related to the existing sewage and water supply system, water inspection boxes, sewage, electricity and telephone networks, building alignments, paved roads, gutters and curb, rock formations, thalwegs, streams, bridges, rainfall drainage and altimetry.

During the data processing phase, the collected points were downloaded to the computer and sent to the DraftSight (DASSAULT, 2011) for elaboration of the drawings, and afterwards grouping of data in layers, with the points being interconnected to form the drawings of the gathered units.

The networks of water and sewage not identified in the field survey were registered based on the existing cadastral plans, taking as a basis the moorings indicated in these areas with corners, lampposts and other reference points, which were later transformed in vectors. 


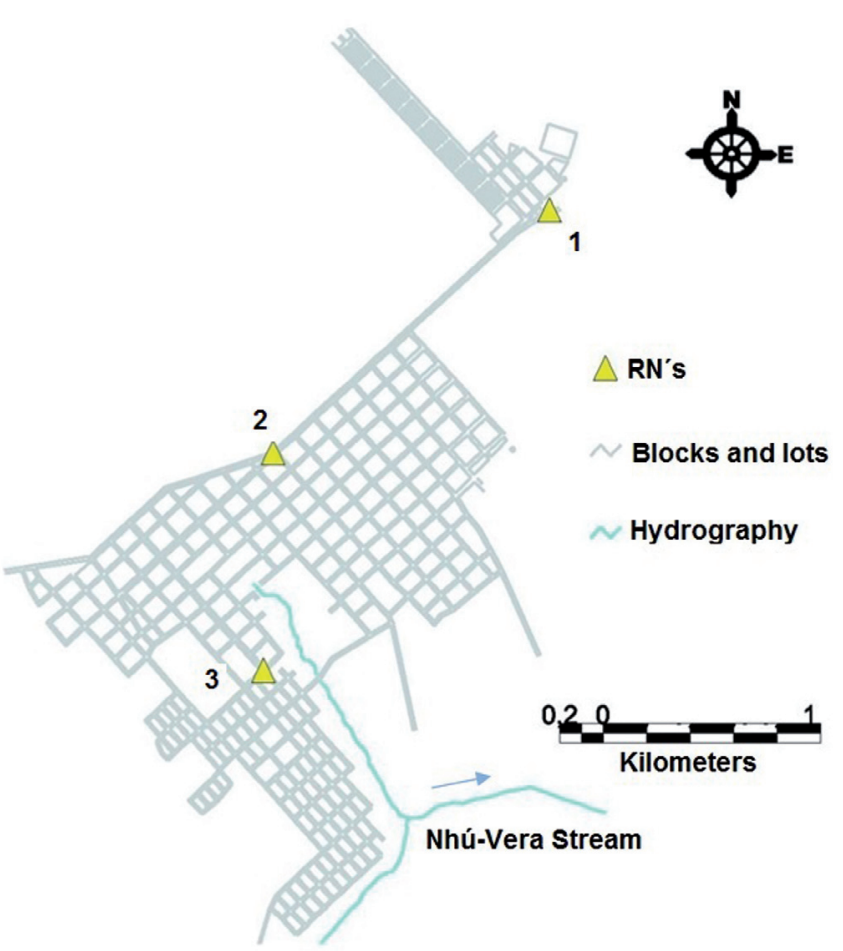

Figure 2 - RN (Level references) location in Coronel Sapucaia / MS

Table 1 - Coordinates of Support Landmarks

Landmarks Used in Topographic Survey of Coronel Sapucaia - MS

\begin{tabular}{ccc}
\hline \multirow{2}{*}{ Identification } & \multicolumn{2}{c}{ Coordinates } \\
\cline { 2 - 3 } & $\mathbf{X}$ & $\mathbf{Y}$ \\
\hline Landmark 1 & 651.402 & 7.427 .028 \\
\hline Landmark 2 & 650.127 & 7.425 .908 \\
\hline Landmark 3 & 650.081 & 7.424 .893 \\
\hline
\end{tabular}

Both water and sanitary sewage networks were assigned to a database with information shown in table 2 , to characterize their diameter, material, date of installation and other information. 
Table 2 - Information table fragment of the registered network

\begin{tabular}{cccccc}
\hline $\begin{array}{c}\text { Coordinates from the } \\
\text { center of the stretch }\end{array}$ & & $\begin{array}{c}\text { Network } \\
\text { material }\end{array}$ & $\begin{array}{c}\text { Network } \\
\text { diameter }\end{array}$ & $\begin{array}{c}\text { Installation } \\
\text { date }\end{array}$ \\
\hline $\mathbf{X}$ & $\mathbf{Y}$ & 7.425 .258 & PVC & 150 & $\mathrm{Dec} / 10$ \\
\hline 649.907 & 7.425 .262 & PVC & 200 & $\mathrm{Dec} / 10$ \\
\hline 649.909 & 7.425 .277 & PVC & 200 & Oct/09 \\
\hline 649.934 & 7.425 .294 & CERAMICS & 300 & Mar/86 \\
\hline 649.957 & & & & \\
\hline
\end{tabular}

The consumer units were registered as a basis in the SANESUL commercial register system. This system saves the history of consumption of each user, and serves as the basis to effect the billing system. To perform its geo-referencing a data dictionary was elaborated (Table 3 ). When the reader of the hydrometer carried out the measurement in the consumer unit with navigation GPS, it registered the geographic point related to the coordinate. The GIS used for such procedure was gvSIG Mobile (VALENCIANA, 2012), and the equipment was a D-GPS Trimble Juno SB (receiver with L1 carrier). Finally, the coordinates were assigned to the spreadsheet of the consumers register (Table 4 ).

Table 3 - Part of the data table for geo-referencing consumption data

\begin{tabular}{ccccc}
\hline \multirow{2}{*}{ Route } & Street name & $\begin{array}{c}\text { Residence } \\
\text { Number }\end{array}$ & \multicolumn{2}{c}{ Coordinates } \\
\cline { 4 - 5 } & João Basílio de Oliveira & 312 & 7.425 .384 & 650.807 \\
\hline 4 & João Basílio de Oliveira & 322 & 7.425 .391 & 650.812 \\
\hline 4 & João Basílio de Oliveira & 456 & 7.425 .411 & 650.832 \\
\hline
\end{tabular}

Table 4 - Part of the user's registration table with water connections

\begin{tabular}{|c|c|c|c|c|c|}
\hline \multirow{2}{*}{ Route } & \multirow{2}{*}{ Street name } & \multirow{2}{*}{$\begin{array}{c}\text { Residence } \\
\text { Number }\end{array}$} & \multicolumn{2}{|c|}{ Coordinates } & \multirow{2}{*}{$\begin{array}{c}\text { Average } \\
\text { Consumption } \\
2010-2012 \\
\left(\mathrm{~m}^{3} / \text { month) }\right.\end{array}$} \\
\hline & & & $\mathbf{x}$ & $\mathbf{Y}$ & \\
\hline 4 & João Basílio de Oliveira & 312 & 7.425 .384 & 650.807 & 15 \\
\hline 4 & João Basílio de Oliveira & 322 & 7.425 .386 & 650.822 & 10 \\
\hline 4 & João Basílio de Oliveira & 456 & 7.425 .394 & 650.824 & 12 \\
\hline
\end{tabular}


To map the performed services, a field control worksheet was prepared to be completed by the plumbers when performing repair and maintenance services in the Coronel Sapucaia/MS system. Due to the low level of education of some workers in the field (plumbers), the spreadsheet was designed in a simplified way, to make the location of the performed service as accurate as possible.

Pressure zones related to the Municipal Water Supply System (Figure 3), inserted in dxf format, were obtained from the EPANET design software (EPA, 2008).

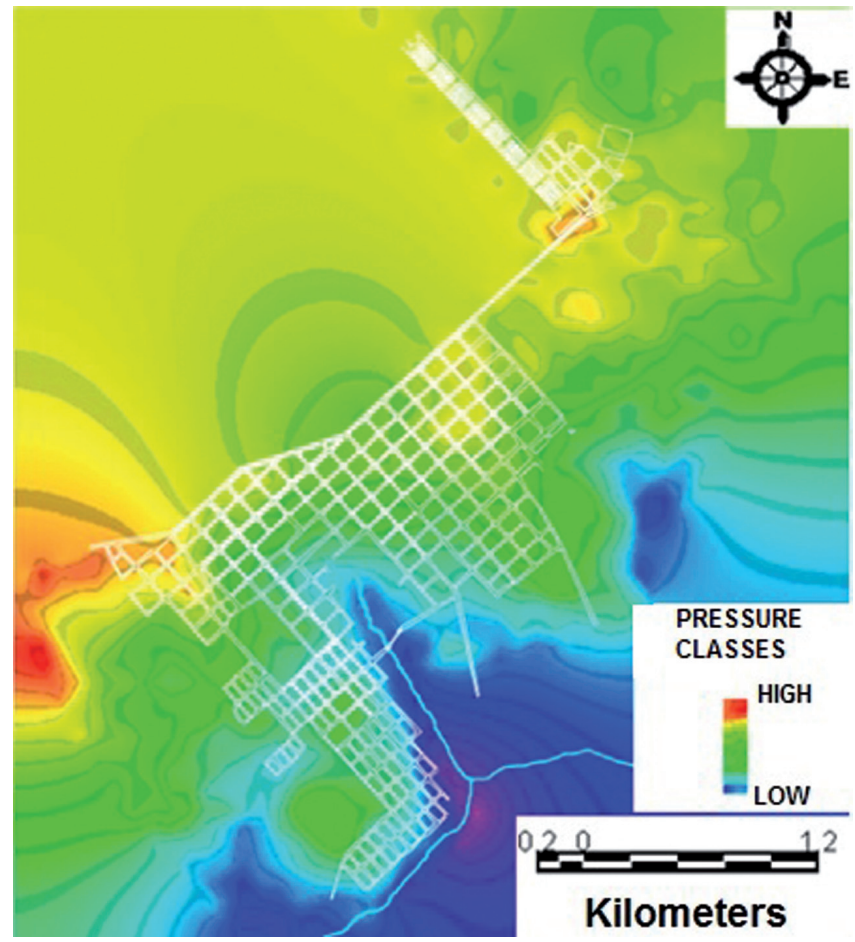

Figure 3 - Pressure classes in meters of water column - mH2O in the water supply network, Coronel Sapucaia/MS

Pressure zones were defined according to the limits established in ABNT 12218/ 94 (ABNT, 1994), being classified as Low (less than $10 \mathrm{mH} 20$ ), Medium (between 10 and $50 \mathrm{mH} 2 \mathrm{O}$ ) and High (above $50 \mathrm{mH} 2 \mathrm{O}$ ).

In order to perform the spatial representation of the service records completed by the plumbers, it was necessary to use to the already composed GIS databank. Considering the street name and the nearest link number, it was possible to georeference the occurrence. In the period from January 2010 to December 2012, 318 registered services distributed according to table 5 were executed.

Data from the services performed in 2010 were the first to be tabulated so that more sensitive regions could be identified for repairs and maintenance in the water supply network, showing more occurrences. This information was used as a basis for guiding preventive and corrective actions by the operational support staff for the subsequent years. 
Table 5 - Activities registered in 2010

in Coronel Sapucaia/MS

\begin{tabular}{cccc}
\hline Service & $\mathbf{2 0 1 0}$ & $\mathbf{2 0 1 1}$ & $\mathbf{2 0 1 2}$ \\
\hline Network Repair & 53 & 42 & 46 \\
\hline $\begin{array}{c}\text { Household Connection } \\
\text { Replacement (HCR) }\end{array}$ & 22 & 13 & 19 \\
\hline Hydrometer Replacement & 17 & 23 & 9 \\
\hline Network Replacement & 15 & 5 & 10 \\
\hline Others & 21 & 9 & 14 \\
\hline
\end{tabular}

The planialtimetric and cadastral survey was carried out with Datum SIRGAS 2000, because it is the new base for the Brazilian Geodetic System (BGS) and for the National Cartographic System (NCS) (IBGE, 2010).

The planialtimetric and cadastral base data were inserted in dwg format layers, individualized by information, and converted to the shp, format within the GIS software to afterwards connect the information databases of the water, sewage and link. The GIS software gvSIG (VALENCIANA, 2015) was used for the elaboration of the works and composition of the system.

\section{RESULTS AND DISCUSSION}

The composition by vector layer with different information from the database resulted in a dynamic GIS that, although robust, was stable for the demands of the work in the execution of tasks involving raster or vector layers.

The data of the services were tabulated and saved in dbf format, according to table 6 , to be later imported into gvSIG for spatial visualization of the information according to figure 4 .

\section{Table 6 - Fragment of the service worksheet tabulated in Coronel Sapucaia}

\begin{tabular}{cccc}
\hline \multicolumn{2}{c}{ Coordinates } & Service & Date \\
\cline { 1 - 2 } $\mathbf{X}$ & $\mathbf{Y}$ & Replacement & $17 / 12 / 2010$ \\
\hline 649.907 & 7.425 .258 & Replacement & $18 / 06 / 2011$ \\
\hline 649.908 & 7.425 .264 & Repair & $19 / 07 / 2012$ \\
\hline 649.947 & 7.425 .295 & $\begin{array}{c}\text { Household Connection } \\
\text { Replacement (HCR) }\end{array}$ & $25 / 01 / 2012$ \\
\hline
\end{tabular}






Figure 4 - Detailed view of the service distribution in the water supply network in Coronel Sapucaia/MS

The low education of the field staff made some of the data acquisition difficult, however, the proposed service worksheet met the information demands. Figure $\mathbf{5}$ presents the information obtained in 2010.



Figure 5 - Map of the service location in the supply network. In the background the pressure zones in Coronel Sapucaia/MS in 2010 
From figure 5 one observes that most network repair and replacement services were concentrated in asbestos cement networks from the high and medium pressures region, which were implanted more than 20 years ago. These targets are constantly monitored they are as well priority areas for infrastructure replacement and new investments.

Along with this mapping, it was also possible to carry out a routine and prevention planning in sensitive regions, with a high index of service requests. Preventive actions were executed in 2011 and 2012, such as the use of geophones in the proximity of repair points. Another key point was the awareness of the nearby population, to immediately alert the SANESUL office in the municipality, as soon as leaks in the supply network were found, as well as the agility and commitment of the staff to solve the problems. As a result, the rate of water loss per link in the municipality reduced gradually, as shown in table 7.

\section{Table 7 - Net loss ratio of treated water per link in Coronel Sapucaia / MS (SANESUL, 2013)}

\begin{tabular}{llll}
\cline { 2 - 4 } & \multicolumn{3}{c}{ Year } \\
\cline { 2 - 4 } & $\mathbf{2 0 1 0}$ & $\mathbf{2 0 1 1}$ & $\mathbf{2 0 1 2}$ \\
\hline Net Loss Ratio. (m²/link/year) & 78,24 & 67,99 & 66,56 \\
\hline
\end{tabular}

\section{CONCLUSIONS}

The nature of the physical infrastructure from basic sanitation, with a life span of several years, justifies already the use of a single database, containing its physical characterization, as well as the history of occurrences and performed maintenances, in a georeferenced form, so that this information can be analyzed together with others of different interest and characteristics, as occurred in this work.

It is clear that, to perform a correct integration between the water and sewage models and the GIS database, a careful planning is necessary with a series of steps to be followed, from the composition of the base, to the form of feeding the system only with a properly designed database, distinct applications and an information system which can share data efficiently.

The gvSIG met the expectations for the adopted work scale, because it has a very intuitive interface, and interoperability with a wide range of software used in geotechnology and engineering, helping to reduce the water loss in the system studied.

Finally, it should be pointed out that the methodology used in this work can be applied in other regions without the need of major adaptations, and can therefore be replicated in the Pantanal and other related areas. 


\section{REFERENCES}

ABNT, Associação Brasileira de Normas Técnicas. ABNT 12218/NB 594: Projeto de rede de distribuição de água para abastecimento público: Procedimento. Rio de Janeiro, RJ: ABNT, 1994.

ABNT, Associação Brasileira de Normas Técnicas. NBR 13133: Execução de levantamento topográfico. Rio de Janeiro: ABNT, 1994.

BRASIL. Governo Federal: Plano Nacional de saneamento Básico. 2012. Available at: <http://www.brasil.gov.br/noticias/arquivos/2012/08/14/brasil-quer-universalizarservico-de-saneamento-basico-ate-2030>. Access in Oct. $12^{\text {th }} 2012$.

DASSAULT, D. S. DraftSight: Professional-grade, free CAD software. 2011. Available at: <http://www.3ds.com/products/draftsight/overview/>. Access in March $19^{\text {th }} 2012$.

EPA. United States Environment Protection Agency: EPANET: Software That Models the Hydraulic and Water Quality Behavior of Water Distribution Piping Systems. 2008. Available at; < http://www.epa.gov/nrmrl/wswrd/dw/epanet.html>. Accesso in Jan. $12^{\text {th }} 2010$.

GOMES, H. P. Sistemas de abastecimento de água. João Pessoa: Universitária UFPB, 2002.

IBGE, Instituto Brasileiro de Geografia e Estatística. Sistema Geodésico Brasileiro: Banco de Dados Geodésicos - Modo Textual. 2007. Available at: <http:// www.bdg.ibge.gov.br/bdg/pdf/relatorio.asp?L1=93542>. Access in: Nov. $12^{\text {th }} 2012$.

IBGE. Instituto Brasileiro de Geografia e Estatistica. Dados Históricos dos Censos. 2011. Available at: <http://www.ibge.gov.br/home/estatistica/populacao/ censohistorico/default_hist.shtm>. Access in Dec. $28^{\text {th }} 2010$.

IBGE, Instituto Brasileiro de Geografia e Estatistica. Projeto SIRGAS 2000. 2010. Available at: < http://www.ibge.gov.br/home/geociencias/geodesia/sirgas_proc/ introducao.shtm>. Access in Nov. $11^{\text {th }} 2011$.

MCKIBBEN, W. Wastewater Collection System Planning With GIS in a Large System. Urisa, 1994.

RAMOS, P. R.; RAMOS, L. A.; LOCH, C. Sensoriamento Remoto como Ferramenta para a Gestão Ambiental e o Desenvolvimento Local. CONGRESSO BRASILEIRO DE CADASTRO TÉCNICO MULTIFINALITÁRIO, 7. Florianópolis, 2004, Anais... Florianópolis: UFSC, COBRAC, 2004.

SANESUL, Empresa de Saneamento de Mato Grosso do Sul. Cadastro de rede de abastecimento de água de Cel Sapucaia/MS. Campo Grande: GEOTEC, 1992.

SANESUL, Empresa de Saneamento de Mato Grosso do Sul. SiiBO- Sistemas de Informações Gerenciais. Campo Grande: GETI, 2013.

SIKORSKI, S. R. Geoprocessamento como instrumento de planejamento urbano. GIS BRASIL, Curitiba, p. 40-45, 1996.

TSUTIYA, M. T. Abastecimento de àgua. 4.ed. São Paulo, SP, Brasil: ABES, 2006.

VALENCIANA, G. Conselleria d'Infraestructures i Transport. gvSIG versão $\mathbf{2 . 2}$. 2012. Available at: <http://www.gvsig.org/web/>. Access in Nov. 15 2015. 